\title{
INTRODUCTION
}

\section{Economics of marine conservation}

\author{
U. R. Sumaila ${ }^{1, *}$, K. I. Stergiou ${ }^{2,3}$ \\ ${ }^{1}$ Fisheries Economics Research Unit, University of British Columbia, 2202 Main Mall, Vancouver, BC V6T 1Z4, Canada \\ ${ }^{2}$ Institute of Marine Biological Resources and Inland Waters, Hellenic Centre for Marine Research, Aghios Kosmas, \\ 16777 Athens, Greece \\ ${ }^{3}$ Department of Zoology, School of Biology, Aristotle University of Thessaloniki, UP Box 134, 54124 Thessaloniki, Greece
}

\begin{abstract}
The objective of this Theme Section (TS) is to explore how economics, in conjunction with ecology and other disciplines (i.e. consilience), can be deployed to support the conservation of marine ecosystem biodiversity, function and services through time, for the benefit of both current and future generations. The TS also demonstrates the considerable progress made in the $60 \mathrm{yr}$ following the pioneering works that practicably established the research discipline of fisheries economics. Eight papers explore various social and economic aspects of marine conservation, and address a variety of broad questions such as: (1) How can ecosystem service assessments be better used to inform policy? (2) How can ecosystem-based management principles be incorporated into governance? (3) Will trade in whaling quotas result in the conservation of whales? (4) How can spatial bioeconomics support effective management and conservation of marine ecosystems? (5) How can the welfare of coastal human populations and marine ecosystems be enhanced? (6) How much of the world's fish stocks are shared? (7) What are the values of the goods and services provided by ecosystems? (8) How large are the financial and ecological deficits (surpluses) of nations?
\end{abstract}

KEY WORDS: Bioeconomics · Fisheries economics · Resource economics · Marine conservation · Ecosystem services

Resale or republication not permitted without written consent of the publisher

\section{THEME SECTION OBJECTIVES}

The quest to achieve what R. Buckminster Fuller so eloquently captured in the following quotation is still ongoing:

'With our minds alone we can discover those principles we need to employ to convert all humanity to success in a new, harmonious relationship with the universe. We have the option to make it.' ${ }^{1}$

Our job, as scholars of the social-ecological system (Berkes et al. 2003), is to apply our minds towards meeting the needs of the current generation of people worldwide, without destroying the environmental and ecological basis essential for future generations to also achieve success.

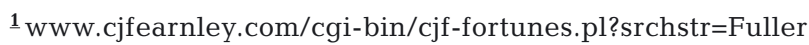
(accessed on June 11, 2015)
}

The objective of this Theme Section (TS) is to explore how economics, in collaboration with ecology and other disciplines, can be deployed to support the conservation of marine ecosystem biodiversity, function and services through time, for the benefit of both current and future generations. The TS also clearly shows that the consilience (Wilson 1998) of different disciplines, such as that achieved in resource economics, bioeconomics, and ecological economicsterms or disciplines that generally have a history going back to the late 1950s, 1970s and 1980s, respectively - is vital for marine conservation (a term with a history of about $50 \mathrm{yr}$ ) (Fig. 1).

The contributions in this volume show us how far we have progressed $60 \mathrm{yr}$ after the pioneering works of Gordon (1954), Scott (1955) and Schaefer (1957), which added the economic aspects of fishing activities to the biological aspects of fisheries, and $40 \mathrm{yr}$ 


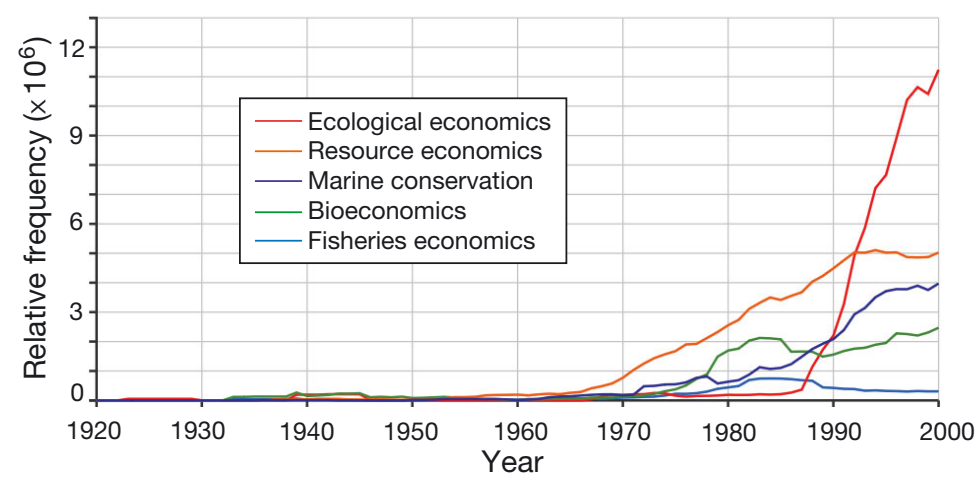

Fig. 1. Relative frequencies of different terms (all forms of 'ecological economics', 'resource economics', 'marine conservation', 'bioeconomics' and 'fisheries economics') in the corpus of English digitized books, extracted using the Ngram Google tool (available online at http:// books.google.com/ngrams). A detailed account of the Ngram technique is provided by Michel et al. (2011) and Lin et al. (2012), and a step-by-step guide for its application using examples is available online at http://books.google.com/ngrams/info\#advanced

after those of Clark (1973) and Clark \& Munro (1975) that practicably established the research discipline of fisheries economics.

\section{STUDIES INCLUDED IN THIS THEME SECTION}

The 23 authors of the 8 articles included in this TS explore various social and economic aspects of marine conservation by addressing the following questions: (1) How can ecosystem service assessments be better used to inform policy (Pendleton et al. 2015)? (2) How can ecosystem-based management principles be incorporated into The Governance of Raja Ampat, New Guinea, Indonesia's West Papua province (Bailey \& Sumaila 2015)? (3) Will trade in whaling quotas result in the conservation of whales (Onofri \& Nunes 2015)? (4) How can spatial bioeconomics support effective management and conservation of marine ecosystems (Cheung \& Sumaila 2015)? (5) How can the welfare of coastal human populations and our coastal marine ecosystems be enhanced (Fisher et al. 2015)? (6) How much of the world's fish stocks are shared, and what are the implications of this for management and conservation of these stocks (Teh \& Sumaila 2015)? (7) What are the values of the goods and services provided by the Chagos Archipelagos (central Indian Ocean) marine ecosystem (Gravestock \& Sheppard 2015)? (8) How large are the financial and ecological deficits (surpluses) of nations (Sumaila et al. 2015)?

Ecosystem service assessments are the principal topic of Pendleton et al. (2015). The authors devel- oped a formalized approach, called a triage, to evaluate what types of ecosystem services should be assessed in order to improve the uptake and usefulness of such information in marine planning. To demonstrate how the approach works, they applied it to 2 case studies in France and the United Kingdom.

Bailey \& Sumaila (2015) developed a simple bioeconomic leader-follower model to simulate snapper (family Lutjanidae) and grouper (family Serranidae) fisheries in Raja Ampat, Indonesia. Their results suggest that current fishing policies do not account for the disproportionate ecosystem effects of destructive fishing. In terms of governance and management, the authors found that elimination of dynamite fishing may be easier for government to achieve due to the high profitability of the live fish trade connected to cyanide fishing. The paper suggests that the Raja Ampat government may benefit by incorporating the ecological externalities of destructive fishing into their EBM planning and ecosystem management.

Onofri \& Nunes (2015) investigated two distinct cases of whale quota regulation: a regime in which quota allocation is an outcome of free market dynamics and a regime in which quotas are allocated via a regulating agency. The authors found that in the first case, no country has the incentive to move away from the allocated quota determined by the market and therefore quota trade will not occur. In the second case, the amount of traded quota depends on the definition of the allocation criterion by the agency.

Cheung \& Sumaila (2015) combine biology and economics using bioeconomic theory to derive a spatially-based vulnerability index of fish stocks. This vulnerability index is based on the intrinsic life-history characteristics of the fish species being targeted and the discount rates of the fishers (that is, the weight that fishers put on future economic benefits from fishers to those they receive now) doing the targeting. The index shows that in the absence of effective management, fish stocks along the northeastern coast of Canada, the Pacific coast of Mexico, the Peruvian coast, the southern and southeastern coasts of Africa, and in the South Pacific and the Antarctic regions, have high vulnerability.

Fisher et al. (2015) examined the wealth, health and educational status of households in over 38000 rural coastal communities across 38 developing countries, using available nationally representative survey data. The authors found that on average, rural communities have 1.5 times lower height-for-age 
standard deviation scores, were 4 times more likely to be poor, and 1.6 times more likely to have low levels of education.

Teh \& Sumaila (2015) focus on shared fisheries, which are economically and biologically significant, but a global picture about their importance relative to total world fisheries catch and economic value is lacking. The authors found, among other things, that the number of participants in shared fisheries has doubled in the past $55 \mathrm{yr}$, and that the most commonly targeted shared species have shifted from those that were mainly restricted to the North Atlantic to those that are highly migratory and are distributed throughout the world.

Gravestock \& Sheppard (2015) provide a preliminary overview of the economic value of the ecosystem goods and services of the Chagos Islands, central Indian Ocean. The authors found that economic flows of several hundred million pounds accrue to society from the Chagos Islands, with a potential economic value in excess of E1billion accruing both regionally in the South West Indian Ocean and globally.

The contribution of Sumaila et al. (2015) highlights the need for countries to look at the dynamics of ecological and financial deficits together when assessing the financial and ecological wellbeing of nations. The authors developed a simple index, the $\mathrm{Eco}^{2}$ index, to rank the combined ecological and financial performance of countries. The authors argue that countries cannot run financial deficits indefinitely and that globally, the ecological deficit cannot be ignored in the long term. Ultimately, ecological deficits weaken the environment, energy sources and food security of nations, with implications for human wellbeing.

\section{FUTURE DIRECTIONS}

This TS raises new issues and questions for future research. For example, political will is vital for efficient management, given that politics is riddled with short-term decision-making (Sumaila \& Walters 2005) and the provision of perverse incentives such as subsidies (Milazzo 1998, Sumaila et al. 2010), and exhibits weak links in management (Browman \& Stergiou 2005). Thus, the question of how the different issues handled in this TS-combined with ecological theory-can act in a synergetic fashion to sensitize both the public and politicians in order to increase political willpower (see e.g. Cardinale \& Svedäng 2008) for managing our oceans is highly relevant.
The economic and social issues discussed in this TS could be extended to tackle ethical issues arising from the human impact on ecosystems (e.g. the extent to which our overexploitation of fisheries resources currently would affect the ability of future generations to meet their own needs from the ocean), as there is increasing concern about the ethical implications of human interactions with the Earth's ecosystems and their biodiversity (Pauly \& Stergiou 2014). For instance, the large-scale removal of organisms from our oceans has serious effects on the structure, function and health of the marine ecosystems that they interact with. Such a huge removal of biomass (recent estimates indicate removals of $>120$ million $\mathrm{t} \mathrm{yr}^{-1}$; Pauly \& Stergiou 2014) raises important ethical issues related to the fate of marine ecosystems and 'the right of future generations to enjoy them as their ancestors did' (Pauly \& Stergiou 2014).

Future research and actions along the lines mentioned above might eventually reverse the present situation in which humans are seen as 'a cancer on the Earth' rather than 'part of the ecosystem' as they used to be (see Pauly 2014, p. 7). In addition, and given the limiting capacity of the planet to support an increasing and technologically advanced human population, such future research and actions might also contribute to the development of new social structures that, together with new, more resourceefficient technologies, are required for solving inequities in resource usage (see Reynolds 2014).

Acknowledgements. The guest editors thank all the contributors to this TS and the reviewers for their valuable comments. U.R.S. thanks the OceanCanada Partnership of the Social Sciences Research Council of Canada for financial support. The guest editors particularly thank Linwood Pendleton and the Agence des Aires marines Protégées for covering $40 \%$ of the cost of publishing all papers in the Theme Section with open access.

\section{LITERATURE CITED}

Anderson LG (1977) The economics of fisheries management. The John Hopkins University Press, Baltimore, MD Anderson LG (1986) The economics of fisheries management. Revised and enlarged edn. The John Hopkins University Press, Baltimore, MD

Bailey M, Sumaila UR (2015) Destructive fishing and fisheries enforcement in eastern Indonesia. Mar Ecol Prog Ser 530:195-211

Berkes F, Colding J, Folke C (eds) (2003) Navigating socialecological systems: building resilience for complexity and change. Cambridge University Press, Cambridge

Browman HI, Stergiou KI (eds) (2005) Politics and socioeconomics of ecosystem-based management of marine resources. Mar Ecol Prog Ser 300:241-296 
Cardinale M, Svedäng H (2008) Mismanagement of fisheries: policy or science? Fish Res 93:244-247

Cheung WWL, Sumaila UR (2015) Economic incentives and overfishing: a bioeconomic vulnerability index. Mar Ecol Prog Ser 530:223-232

Clark CW (1973) The economics of overexploitation. Science 181:630-634

Clark CW (1990) Mathematical bioeconomics. J Wiley \& Sons, New York, NY

Clark CW, Munro GR (1975) The economics of fishing and modern capital theory: a simplified approach. J Environ Econ Manag 2:92-106

Fisher B, Ellis AM, Adams DK, Fox HE, Selig ER (2015) Health, wealth, and education: the socioeconomic backdrop for marine conservation in the developing world. Mar Ecol Prog Ser 530:233-242

> Gordon HS (1954) The economic theory of a commonproperty resource: The fishery. J Polit Econ 62:124-142 (reprinted in Bull Mathem Biol 1991; 1-2:231-252)

Gravestock P, Sheppard C (2015) Valuing the ecosystem services of the Chagos: a review of challenges and estimates. Mar Ecol Prog Ser 530:255-270

Lin Y, Michel JB, Aiden EL, Orwant J, Brockman W, Petrov S (2012) Syntactic annotations for the Google Books Ngram corpus. Proc 50th Annu Meet Assoc Computational Linguistics, Jeju, 8-14 July, 2012. Vol 2: Short papers. Association for Computational Linguistics, Stroudsburg, PA

Michel JB, Shen YK, Aiden AP, Veres A and others (2011) Quantitative analysis of culture using millions of digitized books. Science 331:176-182

Milazzo M (1998) Subsidies in world fisheries: a re-examination. World Bank Tech Pap Fish Ser 406
Onofri L, Nunes PALD (2015) Microeconomic framework for the economics of whales. Mar Ecol Prog Ser 530: $213-222$

Pauly D (2014) Homo sapiens: cancer or parasite? Ethics Sci Environ Polit 14:7-10

Pauly D, Stergiou KI (2014) The ethics of human impacts and the future of the earth's ecosystems: Introduction. Ethics Sci Environ Polit 14:1-5

Pendleton L, Mongruel R, Beaumont N, Hooper T, Charles $M$ (2015) A triage approach to improve the relevance of marine ecosystem services assessments. Mar Ecol Prog Ser 530:183-193

Reynolds CS (2014) On the planetary capacity to sustain human populations. Ethics Sci Environ Polit 14:33-41

Schaefer MB (1957) Some considerations of population dynamics and economics in relation to the management of the commercial marine fisheries. J Fish Res Board Can 14:669-681

Scott A (1955) The fishery: the objectives of sole ownership. J Polit Econ 63: 116-124

Sumaila UR, Walters C (2005) Intergenerational discounting: a new intuitive approach. Ecol Econ 52:135-142

Sumaila UR, Khan A, Dyck A, Watson R, Munro G, Tyedmers P, Pauly D (2010) A bottom up re-estimation of global fisheries subsidies. J Bioeconomics 12:201-225

Sumaila UR, Hotte N, Galli A, Lam VWY, CisnerosMontemayor AM, Wackernagel M (2015) $\mathrm{Eco}^{2}$ : a simple index of economic-ecological deficits. Mar Ecol Prog Ser 530:271-279

Teh LSL, Sumaila UR (2015) Trends in global shared fisheries. Mar Ecol Prog Ser 530:243-254

Wilson EO (1998) Consilience: the unity of knowledge. Alfred A. Knopf, New York, NY 